\title{
Opioid Receptors and Ligands: Targets for Cancer Imaging and Therapy
}

\author{
John R. Lever ${ }^{1,2,3 *}$
}

${ }^{1}$ Department of Radiology, University of Missouri, Columbia, MO 65212 USA

${ }^{2}$ Department of Medical Pharmacology and Physiology, University of Missouri, Columbia, MO 65212 USA

${ }^{3}$ Harry S. Truman Memorial Veterans' Hospital, Columbia, MO 65201 USA

\begin{abstract}
The roles played by classical and non-classical opioid receptors and their ligands in cancer are reviewed, starting with palliation of pain as the traditional linkage, then summarizing current research topics and clinical trials in cancer imaging and therapy, and concluding with a perspective on future directions for the field.
\end{abstract}

Keywords: Morphine; Naltrexone; Naltrindole; Enkephalin; Opioid receptor; Opioid growth factor receptor; Breast cancer; Lung cancer; Pancreatic cancer; PET; SPECT

Abbreviations: Akt: Acutely Transforming Retrovirus AKT8 in Rodent T-cell Lymphoma; mTOR: mammalian Target of Rapamycin; EGFR: Epidermal Growth Factor Receptor; OGFr : Opioid Growth Factor Receptor; LDN: Low Dose Naltrexone; ER: Estrogen Receptor; MAPK / Erk: Mitogen-Activated Protein Kinases / Extracellular SignalRegulated Kinases; SCLC: Small Cell Lung Cancer; PET: Positron Emission Tomography; SPECT: Single Photon Emission Computed Tomography; DO3A: $1: 4: 7$ :10-tetraazacyclododecane-1 :4 :7-triacetic acid; BATTLE: Biomarker-Integrated Approaches of Targeted Therapy for Lung Cancer Elimination; I-SPY TRIAL: Investigation of Serial Studies to Predict your Therapeutic Response with Imaging and Molecular Analysis; ORL: Opioid Receptor-Like

\section{Pain Relief: Traditional Link Between the Opioid System and Cancer}

Morphine, the famous natural product of the opium poppy, was termed "God's own medicine" by renowned physician Sir William Osler [1]. Morphine and related opioid analgesics, such as codeine and oxycodone, are first-line therapy for pain. As a consequence, the opioid system is inseparable from palliative care in clinical oncology, and there are nearly 10,000 literature citations to the use of opioid analgesics for control of cancer pain. Modern pain management with opioids that follows the World Health Organization analgesic ladder is safe and effective [2]. Despite little risk of dependency when opioids are used under such clinical guidelines, an unfortunate tendency persists toward under-treatment of cancer pain that adversely affects quality of life $[2,3]$.

Opioid analgesic actions are mediated by three classical G-protein coupled receptors, denoted mu $(\mu)$, delta $(\delta)$ and kappa $(\kappa)$, which are located in the brain, spinal cord and certain peripheral organs $[4,5]$. In the 1970's, the receptors were identified by radioligand binding techniques, and the endorphin, enkephalin and dynorphin peptides were identified as prominent endogenous ligands [6]. In 1997, highly selective m-peptides, termed endomorphins, were added to the roster of endogenous ligands [7-9]. Interestingly, human cells also synthesize morphine de novo $[10,11]$. PET imaging of $\mu$ opioid receptors in brain was accomplished in 1984 at Johns Hopkins University using the potent agonist $\left[{ }^{11} \mathrm{C}\right]$ carfentanil with Professor Henry Wagner as the first volunteer [12,13]. Several reviews have chronicled the development of $\mathrm{m}, \mathrm{d}$ and $\mathrm{k}$ opioid receptor-binding radiotracers for imaging, and their use in clinical studies of drug abuse, neurological disorders and pain [14-16]. Opioid receptors do not necessarily function independently, and can exist as dimers and heterodimers which modulates their pharmacology, and presents new opportunities for drug development
$[17,18]$. Crystal structures of the $\mu, \delta$ and $\kappa$ opioid receptors bound to prototypical antagonist ligands were reported this year in an outstanding series of articles in the journal Nature [19-21]. This new knowledge should aid in the development of advanced therapeutics.

The analgesia welcomed by cancer patients is primarily mediated by central $\mu$ opioid receptors [22], although peripheral opioid receptors also play key roles [23]. In fact, the development of peripherally restricted opioid analgesics that circumvent centrally mediated side effects, such as respiratory depression, euphoria and mental clouding, is a topic of much current interest [24-26]. Fine-tuning of therapeutic actions is essential, since opioid receptors and their ligands influence a host of physiologic processes including immune, cardiovascular and respiratory functions, feeding behaviors, and smooth muscle contraction $[4,5,27]$. For instance, the centrally active $\mu$ receptor agonists used for relief of chronic cancer pain also activate gastrointestinal opioid receptors, leading to smooth muscle relaxation and constipation. A clinical paradigm for managing bowel dysfunction without affecting analgesia includes parenteral administration of the quaternary salt $N$-methylnaltrexone bromide (Relistor ${ }^{\circledR}$ ), an opioid receptor antagonist that is restricted to the periphery [28].

\section{Classical Opioid Receptors: Molecularly Targeted Imaging and Therapy of Cancer}

Classical opioid receptors, particularly the $\mu$ and $\delta$ types, play important direct roles in cell growth and cancer biology that are moving into the spotlight. Historical perspectives and status updates are given below using breast cancer and lung cancer as illustrations.

\section{Breast cancer}

Over 200,000 new cases of breast cancer are expected for 2012 in the United States alone [29]. Almost thirty-five years ago, the universal $\mu, \delta$ and $\kappa$ opioid receptor antagonists, naloxone and naltrexone, were shown to inhibit the growth of chemically-induced mammary tumors in vivo in rats, with the beneficial effects attributed to central inhibition of hormonal secretions required for breast cancer

*Corresponding author: John R. Lever, Ph.D, Department of Radiology, University of Missouri - Columbia, M292 Medical Sciences Building, One Hospital Drive, Columbia Missouri 65212 USA, Tel: +1-573-814-6000 ext. 53686; Fax: +1-573-814-6551; E-mail: leverj@health.missouri.edu

Received November 16, 2012; Accepted November 23, 2012; Published November 26, 2012

Citation: Lever JR (2012) Opioid Receptors and Ligands: Targets for Cancer Imaging and Therapy. Med chem 2:142-146. doi:10.4172/2161-0444.1000131

Copyright: (c) 2012 Lever JR. This is an open-access article distributed under the terms of the Creative Commons Attribution License, which permits unrestricted use, distribution, and reproduction in any medium, provided the original author and source are credited. 
growth [30]. Radioligand binding studies confirmed that opioid receptors were present on ER-positive breast cancer cells [31,32], and immunohistochemistry studies showed that the vast majority of invasive ductal carcinomas were positive for the endogenous opioid peptides b-endorphin and $\left[\mathrm{Met}^{5}\right]$-enkephalin [33]. About twenty-five years ago, Zagon and colleagues demonstrated that classical opioid receptors were over-expressed in biopsy specimens from several human cancers, including two breast carcinomas [34]. We now know that these receptors are present with sufficient density to allow clinical imaging, and a non-invasive PET study visualized $\mu$ and $\mathrm{d}$ opioid receptors on the primary tumors of a breast cancer patient in 2002 [35]. The $\mu$ receptor agonist, $\left[{ }^{11} \mathrm{C}\right]$ carfentanil [12], and the $\mathrm{d}$ receptor antagonist, $\left[{ }^{11} \mathrm{C}\right]$ methylnaltrindole $[36,37]$, were used as the radioligands (Figure 2). Just this year, an epidemiological investigation of 2,039 breast cancer patients correlated stage at presentation, as well as ten-year survival, with A118G polymorphism of the $\mu$ opioid receptor gene [38]. This provides strong evidence for critical involvement of the opioid system in breast cancer progression.

Opioid receptors and ligands work through complex mechanisms to modulate cell growth and death $[39,40]$, and the effects of systemic morphine on tumor growth remain controversial to this day $[41,42]$. On the other hand, increasing brain levels of the endogenous agonist $\beta$-endorphin, by transplanting $\beta$-endorphin producing neurons into the hypothalamus of rats, causes reduction of chemically-induced mammary tumor incidence, growth and metastasis [43]. Elevated levels of peripheral natural killer cells, macrophage activity and antiinflammatory cytokines were observed. The anti-cancer effects and stimulation of the immune system were naloxone-reversible, indicating an opioid receptor-mediated process. Somewhat paradoxically, laboratory findings consistently indicate that systemic administration of $\mu$ opioid receptor antagonists might be useful for breast cancer therapy [44]. Postulated mechanisms include promotion of ER / $\mu$ opioid receptor cross-talk, inhibition of MAPK / Erk phosphorylation, and down-regulation of nuclear ER activity [45]. At present, patients are being recruited for a Phase II clinical trial designed to assess the efficacy of naltrexone against hormone-refractory metastatic breast cancer [46].

\section{Lung cancer}

Opioid receptors and ligands are under active investigation as molecular targets for imaging and therapy of lung cancer, the leading cause of cancer deaths worldwide [47]. High expression of classical opioid receptors is a feature of many human lung cancers, but not normal lung tissue. Opioid receptors were detected in cell lines established from primary and metastatic sites of SCLC and non-SCLC over twenty years ago $[48,49]$, and the concept of opioid receptors as targets for diagnostic imaging of lung cancer was espoused about fifteen years ago [50,51]. However, the first PET studies of $\mu$ and $d$ opioid receptors in lung cancer patients were reported only five years ago [52]. We used the $\mu$ agonist, $\left[{ }^{11} \mathrm{C}\right]$ carfentanil, and the $\mathrm{d}$ antagonist, $\left[{ }^{11} \mathrm{C}\right]$ methylnaltrindole (Figure 2), to visualize opioid receptors on the primary pulmonary tumors of six SCLC and non-SCLC patients. Uptake of both radioligands was significantly greater in tumors than in normal lung, $\left[{ }^{11} \mathrm{C}\right]$ methylnaltrindole uptake $(\delta)$ was greater than $\left[{ }^{11} \mathrm{C}\right]$ carfentanil uptake $(\mu)$, and tumor receptor binding was blocked in both cases by the universal opioid receptor antagonist naloxone.

These two lipophilic radioligands were developed for brain PET, and are not optimal for peripheral imaging in oncology [14]. A new generation of hydrophilic opioid receptor radioligands, specifically designed for peripheral studies, is now under development. For instance, indium-111 labeled DO3A conjugates of naltrindole (Figure
2) are metabolically stable, maintain very high affinity and selectivity for $\mathrm{d}$ opioid receptors in vitro [53], and bind tenaciously in vivo to $\mathrm{d}$ opioid receptors expressed by SCLC tumor xenografts in mouse models [54]. Indium-111 labeled ligands are intended for SPECT imaging, but extrapolation to include special-purpose radiometals having a range of nuclear properties for PET imaging (Cu-64) or molecularly targeted radiotherapy (Lu-177, Y-90) should be possible. Conjugation of a cyanine dye to the $\mathrm{d}$ opioid receptor peptide Dmt-Tic-Lys has been reported to yield a fluorescent analog suited for complementary in vivo optical imaging studies [55]. So far, attempts to structurally modify $\mu$ opioid peptides, including the endomorphins, with radiometal-labeled substituents for in vivo imaging have not been successful [56].

Silencing either $\mu$ or $\delta$ opioid receptors in lung adenocarcinoma cells inhibits EGFR-induced signaling [57], suggesting the possibility of opioid receptor-based lung cancer therapies. Recent and compelling evidence shows that $\mu$ opioid receptors, in particular, are integral for the regulation of non-SCLC growth. The $\mu$ opioid receptor is overexpressed by 13 of 13 non-SCLC cell lines representing all major histological types, and by 30 biopsy specimens of human non-SCLC tumors with respect to adjacent normal lung [58,59]. Further, silencing $\mu$ receptors, or continuous antagonist blockade with naltrexone or $\mathrm{N}$-methylnaltrexonebromide, inhibits non-SCLCgrowth and metastasis in vivo in animal models $[58,59]$. Moreover, Lewis lung carcinoma cells did not form syngeneic tumors when given to $\mu$ opioid receptor knockout mice [58]. Transfection of a bronchoalveolar carcinoma cell line to induce even greater over-expression of $\mu$ opioid receptors also augmented its flank tumor growth rate and level of lung metastasis

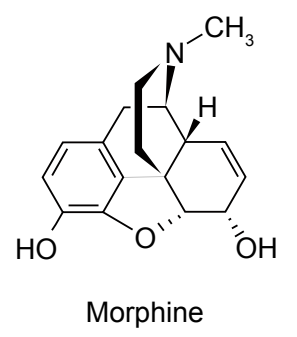

Figure 1: Structures of the $\mu$ opioid receptor agonist morphine and the peripherally restricted antagonist $\mathrm{N}$-methylnaltrexone bromide.
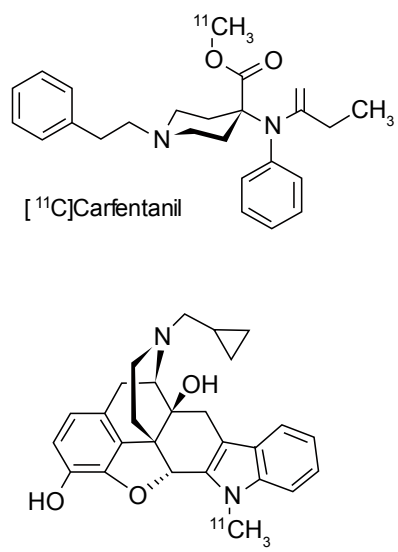

$\left[{ }^{11} \mathrm{C}\right]$ Methylnaltrindole

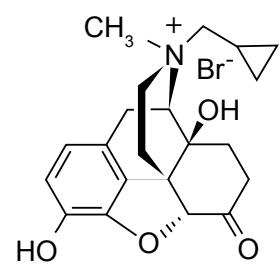

$N$-Methylnaltrexone bromide, Relistor ${ }^{\circledR}$
Figure 2: Radioligands for in vivo imaging of opioid receptors. 
in nude mice [59]. Activation of serine / threonine kinase pathways, Akt and mTOR, are the primary mechanisms identified for $\mu$ opioid receptor mediation of non-SCLC progression [59]. These laboratory studies were driven, in part, by observations made at the University of Chicago that certain cancer patients receiving $N$-methylnaltrexone bromide for relief of $\mu$ opioid-induced constipation exhibited longer than anticipated survival [60]. Thus, $N$-methylnaltrexone bromide (Figure 1) is a promising candidate for repurposing as a lung cancer therapeutic.

\section{Opioid Growth Factor and Receptor for Targeted Therapy of Cancer}

In 1989, Zagon, McLaughlin and colleagues at Pennsylvania State University reported the discovery of a distinct, non-classical binding site for opioids that they initially termed the zeta $(\zeta)$ opioid receptor [61]. Further pioneering work showed the site to be a membrane protein, associated with the nucleus, which bears no structural resemblance to classical opioid receptors located on the cell surface [62]. This site has been renamed the opioid growth factor receptor (OGFr). [Met ${ }^{5}$ enkephalin (Figure 3) has been termed the opioid growth factor (OGF) because of potent inhibition of cancer cell growth through OGFr in vitro when other opioid peptides, such as b-endorphin, were without effect [62]. Activation of OGFr modulates DNA synthesis, and appears to inhibit cell growth by translocation of peptide-receptor complexes adjacent to heterochromatin inside the nucleus [62].

Traditional opioid receptor antagonists, such as naltrexone, also bind to OGFr and can block the actions of [Met $\left.{ }^{5}\right]$-enkephalin. In turn, $\left[\mathrm{Met}^{5}\right]$-enkephalin also binds well to the classical $\delta$ and $\mu$ opioid receptors. Thus, differentiation of the opioid receptor(s) responsible for the various actions of $\left[\mathrm{Met}^{5}\right]$-enkephalin and naltrexone can be difficult. In the early 1980's, before the discovery of the OGFr, studies by Zagon and McLaughlin [63,64] showed that naltrexone modulates neuroblastoma tumors in mice in strikingly dose-dependent fashion. Daily treatments with naltrexone at $0.1 \mathrm{mg} / \mathrm{kg}$ blocked opioid receptors for 6 - 8 hours per day, reduced tumor incidence to $33 \%$, delayed tumor appearance by $98 \%$, and increased survival time by $36 \%$. By contrast, daily treatments with naltrexone at $10.0 \mathrm{mg} / \mathrm{kg}$ blocked opioid receptors for a full 24 hours per day, gave a tumor incidence of $100 \%$, delayed tumor appearance by $27 \%$, and decreased survival time by $19 \%$. Both naltrexone regimens caused up-regulation of classical opioid receptor sites on the tumors, and increased tissue levels of $\beta$-endorphin and [Met $\left.{ }^{5}\right]$-enkephalin by up to six-fold. However, only the chronic low dose naltrexone (LDN) protocol gave significant antitumor effects. Zagon and McLaughlin surmised that endogenous opioids are trophic agents that inhibit tumor growth by suppressing cell proliferation, and that the duration of opioid receptor blockade

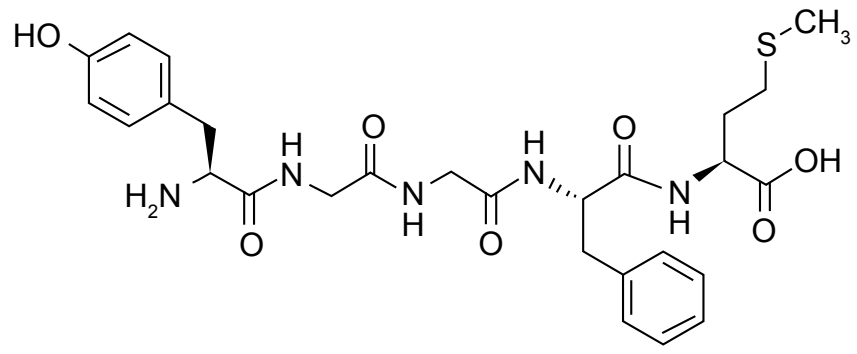

[Met ${ }^{5}$-enkephalin (Tyr-Gly-Gly-Phe-Met)

Figure 3: Structure of $\left[\mathrm{Met}^{5}\right]$-enkephalin, a major endogenous opioid growth factor. by antagonists is critical for modulation of these actions in vivo. Thus, intermittent blockade up-regulates opioid peptides and receptors, leading to decreased tumor cell growth during those times when the antagonist is absent [65].

In 2011, Donahue et al. [66] used an elegant tissue culture model system to show that exposure of cancer cells to naltrexone for a short period of time inhibits their growth, and that up-regulation of OGFr - OGF appears to be uniquely responsible. Ovarian cancer, pancreatic cancer, squamous cell carcinoma of the head and neck, and colorectal cancer cell lines all gave similar results. In companion studies, OGF and LDN were shown to significantly inhibit the progression of human ovarian cancer in a nude mouse model [67], an effect that could be further enhanced by combination with cisplatin, a standard of care chemotherapeutic agent [68]. As discussed in detail by Donahue et al. [66-68], the findings provide mechanistic support for the use of OGF and LDN in cancer therapy. The primary component of their current LDN concept is that repetitive, but short-term, blockade of OGFr with naltrexone increases OGFr number as well as levels of OGF. As naltrexone is eliminated from the body, amplified OGFr and OGF are able to interact again with increased ability to inhibit cancer cell proliferation.

The efficacy of OGF alone for treatment of advanced pancreatic cancer was demonstrated in a recent Phase II clinical trial involving twenty-four patients who had failed standard of care chemotherapy [69]. Weekly treatment with intravenous OGF led to 3-fold longer survival time as compared to untreated patients, and $62 \%$ of subjects who survived more than two months had decreased or stabilized tumor mass. A more limited cohort of four patients with advanced pancreatic cancer exhibited much longer than expected survival in response to a combination of LDN and a-lipoic acid, an enzyme cofactor with antioxidant properties and beneficial effects on immune cell function [70]. In a case report, six months of LDN therapy alone led to significant improvements in lymph node size and metabolic activity for a single patient with B-cell lymphoma [71]. Naltrexone exerts neuroimmunomodulatory effects itself, albeit at higher dosage levels. Lissoni et al. [72,73] documented naltrexone suppression of T helper-2 cell activity and amplification of the anti-cancer cytokine, interleukin 2, in clinical trials involving cancer patients with diverse metastatic solid tumors. Two upcoming clinical trials posted at clinicaltrials.gov will test LDN against metastatic melanoma, castration-resistant prostate cancer and renal cancer [74], and as an agent for improving quality of life in glioma patients [75]. Thus, the LDN concept is gaining traction within the mainstream medical community. LDN is often mentioned on the Internet $[76,77]$ and in the popular press [78] as a promising, inexpensive off-label adjuvant cancer treatment, replete with anecdotal descriptions of beneficial effects.

\section{Perspectives}

The remarkable ability of opioid receptors and opioid analgesics to alleviate pain is their traditional link to cancer, a union that will no doubt continue. However, the relationship is becoming much more meaningful. In their 1986 article in the journal Cancer, Roth and Barchas [48] reported the presence of opioid peptides and receptors on SCLC cells, and presciently stated: "If individual cancers can be defined by the peptides and receptors they express, it may be possible to design rational therapy in an individualized manner." We are fortunate to be in an era where personalized medicine is becoming a reality. Although a challenging proposition, innovative, molecularly targeted therapies for cancer can be matched to the particular patients most likely to benefit [79-81]. The BATTLE trial in lung cancer [82] and the I-SPY TRIAL in breast cancer [83] are major steps forward, showing the feasibility of 
using a patient's own biomarkers to select the best treatment option for them. To note but one important example, non-SCLC patients having EGFR mutations are a small percentage of the total patient population, but are very responsive to tyrosine kinase inhibitors such as erlotinib $\left(\right.$ Tarceva $\left.{ }^{\circledR}\right)$, leading to notable survival benefits [84].

Over the past several years, significant progress has been made in identifying the roles that classical and non-classical opioid receptors and their ligands play in cancer biology, and the pace of discovery has quickened. Some mysteries, and many questions, remain. For instance, relatively little is known about direct involvement of the $\mathrm{k}$ opioid receptor in cancer. More information would be welcome, since a study this year showed that a selective $\mathrm{k}$ agonist inhibits the growth of non-SCLC cells, in naloxone-reversible fashion, through a mechanism involving death-promoting glycogen synthase kinase 3b [85]. Scant information is available relating the fourth recognized opioid receptor, $\mathrm{ORL}_{1}$, to cancer. $\mathrm{ORL}_{1}$, also known as the nociceptin / orphanin FQ receptor, is an intriguing G-protein-coupled site that displays about $60 \%$ sequence homology to the classical opioid receptors, but does not bind most traditional opioids because of conformational differences in its ligand binding pockets $[86,87] . \mathrm{ORL}_{1}$ activation may cause inhibition of pro-inflammatory cytokines and chemokines [88], but more specific connections to cancer remain to be established. An emerging topic for exploration is modulation of $\mu$ and $\mathrm{d}$ opioid receptor homo- and heterodimerization in vivo, a phenomenon which influences mammary tumor growth in a rat model by an unknown mechanism [89].

Abundant evidence shows that cancer therapy mediated by opioid receptors and their ligands is a real possibility. Phase II clinical trials with OGF, as well as high- and low-dose naltrexone, are already being conducted with some success. The anticancer effects to be gained from continuous opioid receptor blockade, as discussed above for breast and lung cancer therapy in animal models, would not be likely under the mechanistic paradigm of LDN alone. On the other hand, LDN clearly is effective in some animal models when continuous receptor blockade is not. Taken together, the available laboratory data point to multiple mechanisms for opioid actions on cancer cell growth that involve the classical opioid receptors, as well as the putative non-classical OGFr that has not been as widely studied. The effects observed are often dependent upon study specifics. Thus, routine clinical integration of opioid-mediated cancer therapy will require a much better understanding of the complex interplay between the various molecular mechanisms that may be involved, as well as concrete results from wellstructured clinical research trials.

Molecular imaging is sure to play a part in the continued translation of the research into the clinic. Taking the personalized medicine approach, one might envision $\mu$ opioid receptor PET as a way to stratify lung cancer patients into a cohort that would benefit from $\mu$ receptor antagonist therapy. Perhaps patients with cancers that over-express $\mathrm{d}$ opioid receptors could be identified by SPECT using a ligand labeled with the g-emitter In-111, and then treated by targeted radiotherapy using an analog labeled with a cell-killing b-emitter such as Y-90. In addition to their complex effects on cancer cell growth, opioid receptors and their ligands also mediate many normal functions. Thus, the therapeutic "window" for opioids in oncology might be narrow, but is definitely worth opening.

\section{Acknowledgements}

The author thanks Dr. Susan Z. Lever for helpful discussions and a critical reading of this manuscript, and the reviewers for constructive comments. The author acknowledges the National Cancer Institute (P50 CA103130; P01 CA32845) and the National Institute on Drug Abuse (R01 DA08870; R01 DA08816) for opioid receptor research support. Resources provided by the University of Missouri Life Sciences Mission Enhancement Program, and by the Harry S. Truman Memorial Veterans' Hospital also are appreciated.

\section{References}

1. Golden RL (2009) William Osler, urolithiasis, and God's own medicine. Urology 74: $517-521$

2. Ripamonti $\mathrm{Cl}$, Bandieri E, Roila F (2011) Management of cancer pain: ESMO clinical practice guidelines. Ann Oncol 22 (Suppl 6): vi69-77.

3. Zoëga S, Fridriksdottir N, Sigurdardottir V, Gunnarsdottir S (2012) Pain and other symptoms and their relationship to quality of life in cancer patients on opioids. Qual Life Res

4. McNally GP, Akil H (2002) Opioid peptides and their receptors: overview and function in pain modulation. In: Davis KL, Charney DS, Coyle JT, Nemeroff CB (eds). Neuropsychopharmacology: The Fifth Generation of Progress. Lippincott Williams \& Wilkins: Philadelphia, PA. pp 35-46.

5. Waldhoer M, Bartlett SE, Whistler JL (2004) Opioid receptors. Annu Rev Biochem 73: 953-990.

6. Snyder SH, Pasternak GW (2003) Historical review: Opioid receptors. Trends Pharmacol Sci 24: 198-205

7. Zadina JE, Hackler L, Ge LJ, Kastin AJ (1997) A potent and selective endogenous agonist for the mu-opiate receptor. Nature 386: 499-502.

8. Hackler L, Zadina JE, Ge LJ, Kastin AJ (1997) Isolation of relatively large amounts of endomorphin-1 and endomorphin-2 from human brain cortex. Peptides 18: 1635-1639.

9. Liu WX, Wang R (2012) Endomorphins: potential roles and therapeutic indications in the development of opioid peptide analgesic drugs. Med Res Rev 32: $536-580$

10. Poeaknapo C, Schmidt J, Brandsch M, Dräger B, Zenk MH (2004) Endogenous formation of morphine in human cells. Proc Natl Acad Sci U S A 101: 14091 14096.

11. Stefano GB, Ptácek R, Kuželová H, Kream RM (2012) Endogenous morphine: up-to-date review 2011. Folia Biol (Praha) 58: 49-46.

12. Frost JJ, Wagner HN Jr, Dannals RF, Ravert HT, Links JM, et al. (1985) Imaging opiate receptors in the human brain by positron tomography. J Comput Assist Tomogr 9: 231-236.

13. Frost JJ (2001) PET imaging of the opioid receptor: the early years. Nucl Med Biol 28: 509-513.

14. Lever JR (2007) PET and SPECT imaging of the opioid system: receptors, radioligands and avenues for drug discovery and development. Curr Pharm Des 13: 33-49.

15. Ravert HT, Bencherif B, Madar I, Frost JJ (2004) PET imaging of opioid receptors in pain: progress and new directions. Curr Pharm Des 10: 759-768.

16. Henriksen G, Willoch F (2008) Imaging of opioid receptors in the central nervous system. Brain 131: 1171-1196.

17. Jordan BA, Cvejic S, Devi LA (2000) Opioids and their complicated receptor complexes. Neuropsychopharmacology 23: S5-5S18.

18. Gupta A, Décaillot FM, Devi LA (2006) Targeting opioid receptor heterodimers: strategies for screening and drug development. AAPS J 8: E153-159.

19. Manglik A, Kruse AC, Kobilka TS, Thian FS, Mathiesen JM, et al. (2012) Crysta structure of the $\mu$-opioid receptor bound to a morphinan antagonist. Nature 485 321-326.

20. Wu H, Wacker D, Mileni M, Katritch V, Han GW, et al. (2012) Structure of the human $\hat{l}^{\circ}$-opioid receptor in complex with JDTic. Nature 485: 327-332.

21. Granier S, Manglik A, Kruse AC, Kobilka TS, Thian FS, et al. (2012) Structure of the d-opioid receptor bound to naltrindole. Nature 485: 400-404.

22. Pasternak GW (2010) Molecular insights into mu opioid pharmacology: From the clinic to the bench. Clin J Pain 26 Suppl 10: S3-9.

23. Stein C, Clark JD, Oh U, Vasko MR, Wilcox GL, et al. (2009) Periphera mechanisms of pain and analgesia. Brain Res Rev 60: 90-113.

24. Sehgal N, Smith HS, Manchikanti L (2011) Peripherally acting opioids and clinical implications for pain control. Pain Physician 14: 249-258.

25. Vadivelu N, Mitra S, Hines RL (2011) Peripheral opioid receptor agonists for analgesia: a comprehensive review. J Opioid Manag 7: 55-68.

26. Spetea M, Schmidhammer H (2012) Recent advances in the development of 14-alkoxy substituted morphinans as potent and safer opioid analgesics. Cur Med Chem 19: 2442-2457. 
27. Feng Y, He X, Yang Y, Chao D, Lazarus LH, et al. (2012) Current research on opioid receptor function. Curr Drug Targets 13: 230-246.

28. Gatti A, Sabato AF (2012) Management of opioid-induced constipation in cancer patients: focus on methylnaltrexone. Clin Drug Investig 32: 293-301.

29. Siegel R, Naishadham D, Jemal A (2012) Cancer statistics, 2012. CA Cancer J Clin 62: 10-29.

30. Aylsworth CF, Hodson CA, Meites J (1979) Opiate antagonists can inhibit mammary tumor growth in rats. Proc Soc Exp Biol Med 161: 18-20.

31. Maneckjee R, Biswas R, Vonderhaar BK (1990) Binding of opioids to human MCF-7 breast cancer cells and their effects on growth. Cancer Res 50: 22342238.

32. Hatzoglou A, Bakogeorgou E, Castanas E (1996) The antiproliferative effect of opioid receptor agonists on the T47D human breast cancer cell line, is partially mediated through opioid receptors. Eur J Pharmacol 296: 199-207.

33. Chatikhine VA, Chevrier A, Chauzy C, Duval C, d'Anjou J, et al. (1994) Expression of opioid peptides in cells and stroma of human breast cancer and adenofibromas. Cancer Lett 77: 51-56.

34. Zagon IS, McLaughlin PJ, Goodman SR, Rhodes RE (1987) Opioid receptors and endogenous opioids in diverse human and animal cancers. J Natl Cancer Inst 79: 1059-1065.

35. Villemagne PS, Dannals RF, Ravert HT, Frost JJ (2002) PET imaging of human cardiac opioid receptors. Eur J Nucl Med Mol Imaging 29: 1385-1388.

36. Lever JR, Scheffel U, Kinter CM, Ravert HT, Dannals RF, et al. (1992) In vivo binding of $\mathrm{N}^{\prime}-([11 \mathrm{C}]$ methyl)naltrindole to $\mathrm{d}$ opioid receptors in mouse brain. Eur J Pharmacol 216: 459-460.

37. Madar I, Lever JR, Kinter CM, Scheffel U, Ravert HT, et al. (1996) Imaging of delta opioid receptors in human brain by N1'-([11C]methyl)naltrindole and PET. Synapse 24: 19-28

38. Bortsov AV, Millikan RC, Belfer I, Boortz-Marx RL, Arora H, et al. (2012) Î1/4Opioid receptor gene $\mathrm{A} 118 \mathrm{G}$ polymorphism predicts survival in patients with breast cancer. Anesthesiology 116: 896-902.

39. Tegeder I, Geisslinger G (2004) Opioids as modulators of cell death and survival--unraveling mechanisms and revealing new indications. Pharmacol Rev 56: 351-369.

40. Fichna J, Janecka A (2004) Opioid peptides in cancer. Cancer Metastasis Rev 23: 351-366.

41. Gach K, WyrÄ ${ }^{T M}$ bska A, Fichna J, Janecka A (2011) The role of morphine in regulation of cancer cell growth. Naunyn Schmiedebergs Arch Pharmacol 384: 221-230.

42. Luk K, Boatman S, Johnson KN, Dudek OA, Ristau N, et al. (2012) Influence of morphine on pericyte-endothelial interaction: implications for antiangiogenic therapy. J Oncol 2012: 458385.

43. Sarkar DK, Zhang C, Murugan S, Dokur M, Boyadjieva NI, et al. (2011) Transplantation of $\hat{i}^{2}$-endorphin neurons into the hypothalamus promotes immune function and restricts the growth and metastasis of mammary carcinoma. Cancer Res 71: 6282-6291.

44. Gupta K, Kshirsagar S, Chang L, Schwartz R, Law PY, et al. (2002) Morphine stimulates angiogenesis by activating proangiogenic and survival-promoting signaling and promotes breast tumor growth. Cancer Res 62: 4491-4498.

45. Farooqui M, Geng ZH, Stephenson EJ, Zaveri N, Yee D, et al. (2006) Naloxone acts as an antagonist of estrogen receptor activity in MCF-7 cells. Mol Cancer Ther 5: 611-620.

46. Masonic Cancer Center, University of Minnesota. Phase II study of naltrexone for the treatment of hormone-refractory, metastatic breast cancer.

47. Jemal A, Bray F, Center MM, Ferlay J, Ward E, et al. (2011) Global cancer statistics. CA Cancer J Clin 61: 69-90.

48. Roth KA, Barchas JD (1986) Small cell carcinoma cell lines contain opioid peptides and receptors. Cancer 57: 769-773.

49. Maneckjee R, Minna JD (1990) Opioid and nicotine receptors affect growth regulation of human lung cancer cell lines. Proc Natl Acad Sci U S A 87: 3294 3298.

50. Campa MJ, Schreiber G, Bepler G, Bishop MJ, McNutt RW, et al. (1996) Characterization of delta opioid receptors in lung cancer using a nove nonpeptidic ligand. Cancer Res 56: 1695-1701.
51. Schreiber G, Campa MJ, Prabhakar S, O'Briant K, Bepler G, et al. (1998) Molecular characterization of the human delta opioid receptor in lung cancer Anticancer Res 18: 1787-1792.

52. Madar I, Bencherif B, Lever J, Heitmiller RF, Yang SC, et al. (2007) Imaging delta- and mu-opioid receptors by PET in lung carcinoma patients. J Nucl Med 48: $207-213$

53. Duval RA, Allmon RL, Lever JR (2007) Indium-labeled macrocyclic conjugates of naltrindole: high-affinity radioligands for in vivo studies of peripheral delta opioid receptors. J Med Chem 50: 2144-2156.

54. Lever JR, Watkinson LD, Fergason EA, Carmack TL, Duval RA (2007) In vivo localization of delta opioid receptors on human small cell lung cancer xenografts in SCID mice using an indium-111 labeled DO3A conjugate of naltrindole. J Nucl Med 48S2: 333P.

55. Josan JS, Morse DL, Xu L, Trissal M, Baggett B, et al. (2009) Solid-phase synthetic strategy and bioevaluation of a labeled delta-opioid receptor ligand Dmt-Tic-Lys for in vivo imaging. Org Lett 11: 2479-2482.

56. Fichna J, Janecka A, Kosson P, Maecke HR (2004) Synthesis of HYNICand DOTA-conjugates with $\mathrm{m}$-opioid receptor ligands: morphiceptin and endomorphin-2. Polish J Chem 78: 951-959.

57. Fujioka N, Nguyen J, Chen C, Li Y, Pasrija T, et al. (2011) Morphine-induced epidermal growth factor pathway activation in non-small cell lung cancer Anesth Analg 113: 1353-1364.

58. Mathew B, Lennon FE, Siegler J, Mirzapoiazova T, Mambetsariev N, et al. (2011) The novel role of the mu opioid receptor in lung cancer progression: a laboratory investigation. Anesth Analg 112: 558-567.

59. Lennon FE, Mirzapoiazova T, Mambetsariev B, Salgia R, Moss J, et al (2012) Overexpression of the $11 / 4$-opioid receptor in human non-small cell lung cancer promotes Akt and mTOR activation, tumor growth, and metastasis. Anesthesiology 116: 857-867.

60. Lennon FE, Moss J, Singleton PA (2012) The $11 \frac{1}{4}$-opioid receptor in cance progression: is there a direct effect? Anesthesiology 116: 940-945.

61. Zagon IS, Goodman SR, McLaughlin PJ (1989) Characterization of zeta (zeta) a new opioid receptor involved in growth. Brain Res 482: 297-305

62. Zagon IS, Verderame MF, McLaughlin PJ (2002) The biology of the opioid growth factor receptor (OGFr). Brain Res Brain Res Rev 38: 351-376.

63. Zagon IS, McLaughlin PJ (1983) Naltrexone modulates tumor response in mice with neuroblastoma. Science 221: 671-673.

64. McLaughlin PJ, Zagon IS (1987) Modulation of human neuroblastoma transplanted into nude mice by endogenous opioid systems. Life Sci 41: 14651472.

65. Zagon IS, McLaughlin PJ (1989) Opioid antagonist modulation of murine neuroblastoma: a profile of cell proliferation and opioid peptides and receptors Brain Res 480: 16-28.

66. Donahue RN, McLaughlin PJ, Zagon IS (2011) Low-dose naltrexone targets the opioid growth factor-opioid growth factor receptor pathway to inhibit cell proliferation: mechanistic evidence from a tissue culture model. Exp Biol Med (Maywood) 236: 1036-1050.

67. Donahue RN, McLaughlin PJ, Zagon IS (2011) The opioid growth factor (OGF) and low dose naltrexone (LDN) suppress human ovarian cancer progression in mice. Gynecol Oncol 122: 382-388.

68. Donahue RN, McLaughlin PJ, Zagon IS (2011) Low-dose naltrexone suppresses ovarian cancer and exhibits enhanced inhibition in combination with cisplatin. Exp Biol Med (Maywood) 236: 883-895.

69. Smith JP, Bingaman SI, Mauger DT, Harvey HH, Demers LM, et al. (2010) Opioid growth factor improves clinical benefit and survival in patients with advanced pancreatic cancer. Open Access J Clin Trials 2010: 37-48.

70. Berkson BM, Rubin DM, Berkson AJ (2009) Revisiting the ALA/N (alpha-lipoic acid/low-dose naltrexone) protocol for people with metastatic and nonmetastatic pancreatic cancer: a report of 3 new cases. Integr Cancer Ther 8: 416-422.

71. Berkson BM, Rubin DM, Berkson AJ (2007) Reversal of signs and symptoms of a B-cell lymphoma in a patient using only low-dose naltrexone. Integr Cance Ther 6: 293-296.

72. Lissoni $P$, Malugani $F$, Malysheva O, Kozlov V, Laudon M, et al. (2002) Neuroimmunotherapy of untreatable metastatic solid tumors with subcutaneous low-dose interleukin-2, melatonin and naltrexone: modulation of interleukin-2 induced antitumor immunity by blocking the opioid system. Neuro Endocrinol Lett 23: 341-344. 
Citation: Lever JR (2012) Opioid Receptors and Ligands: Targets for Cancer Imaging and Therapy. Med chem 2:142-146. doi:10.4172/21610444.1000131

73. Lissoni P, Malugani F, Bordin V, Conti A, Maestroni G, et al. (2002) A new neuroimmunotherapeutic strategy of subcutaneous low-dose interleukin-2 plus the long-acting opioid antagonist naltrexone in metastatic cancer patients progressing on interleukin-2 alone. Neuro Endocrinol Lett 23: 255-258.

74. Debora G. Isdale, Brown University. Low dose naltrexone for metastatic melanoma, castrate resistant prostate cancer and renal cancer: a Phase II Brown University oncology group research study.

75. Katy Peters, Duke University Medical Center. Effects of low-dose naltrexone on quality of life in high-grade glioma patients: a placebo-controlled, double-blind randomized trial.

76. Monastersky N, Landau SC (2006) Future of emergency contraception lies in pharmacists' hands. J Am Pharm Assoc (2003) 46: 84-88.

77. Brown N, Panksepp J (2009) Low-dose naltrexone for disease prevention and quality of life. Med Hypotheses 72: 333-337.

78. Moore EA, Wilkinson $S$ (2009) The promise of low dose naltrexone therapy: potential benefits in cancer, autoimmune, neurological and infectious disorders. McFarland: Jefferson, NC.

79. Cho SH, Jeon J, Kim SI (2012) Personalized medicine in breast cancer: a systematic review. J Breast Cancer 15: 265-272.

80. Ansari D, Chen BC, Dong L, Zhou MT, Andersson R (2012) Pancreatic cancer: translational research aspects and clinical implications. World J Gastroenterol 18: 1417-1424

81. Wu K, House L, Liu W, Cho WC (2012) Personalized targeted therapy for lung cancer. Int J Mol Sci 13: 11471-11496.
82. Kim ES, Herbst RS, Wistuba II, Lee JJ, Blumenschein GR Jr, et al. (2011) The BATTLE trial: personalizing therapy for lung cancer. Cancer Discov 1: 44-53.

83. Esserman LJ, Berry DA, Cheang MC, Yau C, Perou CM, et al. (2012) Chemotherapy response and recurrence-free survival in neoadjuvant breast cancer depends on biomarker profiles: results from the I-SPY 1 TRIAL (CALGB 150007/150012; ACRIN 6657). Breast Cancer Res Treat 132: 1049-1062.

84. Zhou C, Wu YL, Chen G, Feng J, Liu XQ, et al. (2011) Erlotinib versus chemotherapy as first-line treatment for patients with advanced EGFR mutation-positive non-small-cell lung cancer (OPTIMAL, CTONG-0802): a multicentre, open-label, randomised, phase 3 study. Lancet Oncol 12: 735-742.

85. Kuzumaki N, Suzuki A, Narita M, Hosoya T, Nagasawa A, et al. (2012) Effect of $\hat{l}^{\circ}$-opioid receptor agonist on the growth of non-small cell lung cancer (NSCLC) cells. Br J Cancer 106: 1148-1152.

86. Chiou LC, Liao YY, Fan PC, Kuo PH, Wang CH, et al. (2007) Nociceptin/ orphanin FQ peptide receptors: pharmacology and clinical implications. Curr Drug Targets 8: 117-135.

87. Thompson AA, Liu W, Chun E, Katritch V, Wu H, et al. (2012) Structure of the nociceptin/orphanin FQ receptor in complex with a peptide mimetic. Nature 485: 395-399.

88. Finley MJ, Happel CM, Kaminsky DE, Rogers TJ (2008) Opioid and nociceptin receptors regulate cytokine and cytokine receptor expression. Cell Immunol 252: $146-154$.

89. Sarkar DK, Sengupta A, Zhang C, Boyadjieva N, Murugan S (2012) Opiate antagonist prevents $\hat{I}^{1} / 4^{-}$- and $\hat{I}^{\prime}$-opiate receptor dimerization to facilitate ability of agonist to control ethanol-altered natural killer cell functions and mammary tumor growth. J Biol Chem 287: 16734-16747. 